\title{
Personalized Versus Socialized Charismatic Leader: Autobiografi Pelayanan Simson Sebagai Hakim Israel
}

\author{
Sonny Eli Zaluchu
}

Sekolah Tinggi Teologia Baptis Indonesia

Email: sonnyzaluchu@stbi.ac.id

Diterima: 6 April 2020

Direvisi: 28 Mei 2020

Disetujui: 11 Juni 2020

\begin{abstract}
Abstrak
Kehidupan Simson adalah sebuah studi kepemimpinan yang menarik untuk dikaji. Selama dua puluh tahun menjadi hakim Israel, Simson tampil dengan kekuatan supernatural Allah yang tak tertandingi. Tetapi, awal yang baik itu tidak berakhir dengan tuntas. Simson memerlihatkan kelemahan karakter, dekadensi moral dan pembangkangan terhadap aturan kenaziran yang seharusnya ditaatinya. Simson jatuh ke dalam pelukan berbagai wanita kafir dan kekuatannya hilang akibat rayuan maut Delila. Simson mengira dirinya masih dipakai Tuhan, tetapi kenyataannya berakhir di penggilingan. Penelitian ini merupakan autobiography research yang berfokus pada kehidupan Simson. Framing yang dipergunakan di dalam analisis adalah pendekatan kepemimpinan (leadership). Temuan memerlihatkan bahwa Simson menekankan tipe kepemimpinan personalized charismatic leader. Pengalaman kepemimpinan Simson memberikan dua basis lingkungan yang seharusnya ada di ruang lingkup seorang pemimpin. Pertama basis sosial. Pemimpin yang berada di dalam basis sosial yang baik akan mendapat dukungan moral, emosi dan strategi dari orangorang yang ada disekitarnya. Melaluinya pemimpin menjalani kekuasannya tidak otoriter, tidak mutlak dan egaliter. Basis kedua adalah lingkungan rohani. Panggilan pelayanan harus diimbangi dengan kehidupan rohani yang kuat. Hanya dengan cara ini seorang pemimpin tetap berada di dalam panggilannya, mengutamakan panggilan dan menjalaninya dengan takut akan Tuhan. Kepemimpinan memang selalu membawa hal-hal korup. Tetapi jika kedua basis
\end{abstract}


ini secara ketat menempel seorang pemimpin, sebesar apapun kekuasaan yang dimilikinya, tetap tidak dapat diselewengkan tanpa diketahui dan dievaluasi.

Kata-Kata Kunci: Delila; Kelemahan; Kepemimpinan; Pemimpin; Simson.

\section{Abstract}

Samson's life is exciting to study of leadership. During his twenty years as a judge of Israel, Samson appeared with the supernatural power of God unmatched. However, a good start does not end ultimately. Samson shows the character's weaknesses, moral decadence, and defiance of the rules of alienation that he should obey. Samson fell into the happy embrace of pagan women, and his strength lost due to Delilah's deadly seduction. Samson thinks that God still uses him, but the reality ends in the mill. This research is autobiography research that focuses on Samson's life. The framing used in the analysis is the leadership approach. The findings show that Samson emphasized the leadership type of personalized charismatic leader. Simson's leadership experience provides two bases of an environment that should exist within the scope of a leader. First, the social basis. Leaders who are in an excellent social base will get moral, emotional, and strategic support from the people around them. Through it, the leader is not authoritarian, not absolute, and egalitarian. The second base is the spiritual environment. The call to service must be balanced with a healthy spiritual life. Only in this way can a leader remain in his calling, giving priority to his calling and living it out of fear of God. Leadership, indeed, always brings corrupt things. However, if these two bases are tightly attached to a leader, no matter how much power he has, it still cannot be distorted without being known and evaluated.

Keywords: Delilah; Leader; Leadership; Samson.

\section{Pendahuluan}

Simson dikenal di dalam dua hal selama menjadi hakim Israel. Pertama, Tuhan memakainya sangat hebat dengan kemampuan supernatural, sehingga musuh Israel saat itu, bangsa Filistin, takluk dan tidak mampu melanjutkan intimidasi militer ke wilayah Israel. Berkali-kali, seorang diri Simson menghadapi orang-orang Filistin dengan menggunakan kekuatan Allah yang dikaruniakan kepadanya sejak lahir. Lang menyebutnya sebagai divine power. ${ }^{1}$ Dengan menggunakan

${ }^{1}$ Bernhard Lang, "God Almighty: Divine Power and Authority in the Biblical and Patristic Periods," in The Infinity of God, ed. B.P. Göcke (University of Notre Dame Press, 2019), 187-211. 
kekuatan tersebut Simson berkali-kali mengalahkan dan memermalukan orangorang Filistin. Sekaligus membuktikan kepada bangsa Israel bahwa Tuhan tidak membiarkan bangsa pilihan-Nya. Berbagai upaya dilakukan oleh orang-orang Filistin untuk mencari tahu letak kelemahan Simson tetapi usaha tersebut selalu menemui jalan buntu. Hingga pada satu titik, Simson berjumpa dengan Delila, yang kemudian menjadi jerat baginya. Wanita itu diperalat musuh untuk menaklukan Simson dan berhasil. Itulah hal kedua yang membuat Simson termasuk sebagai pemimpin di dalam Perjanjian Lama (PL) yang disebut unfinish well. Clinton mengatakan, di antara semua pemimpin di dalam Alkitab yang dipanggil untuk melayani, hanya sedikit yang menyelesaikan tugasnya hingga tuntas. Simson termasuk salah satu yang tidak tuntas. ${ }^{2}$ Tidak sadar bahwa Allah menyertainya dan tidak sadar kalau Allah telah meninggalkannya. ${ }^{3}$ Kredibilitasnya sebagai nazir Allah runtuh. Posisinya berubah dari pahlawan gagah perkasa yang ditakuti musuh, menjadi objek lelucon di rumah pertemuan orang Filistin. Roh Allah telah meninggalkan sang nazir tanpa disadarinya. Narasi di dalam Kitab Hakim-Hakim sangat deskriptif ketika penulisnya memaparkan bahwa Simson mengira dirinya masih dipakai Tuhan ditengah fakta bahwa roh tersebut ternyata sudah undur daripadanya. "Seperti yang sudah-sudah, aku akan bebas dan akan meronta lepas." Tetapi tidaklah diketahuinya, bahwa TUHAN telah meninggalkan dia (Hakim-hakim 16:20).

Dalam bukunya berjudul Finishing Well, Wong mengatakan bahwa jika dibandingkan antara mengawali dengan mengakhiri sesuatu hal, terutama di dalam hal kepemimpinan, mengawali sesuatu tidak lebih sulit daripada mengakhirinya. Terlebih, jika menggunakan konsep, bahwa seorang pemimpin yang dipilih oleh Tuhan, seharusnya mengakhiri kepemimpinannya dengan baik dan tuntas. Ada dua poin penting yang dikemukakannya. Pertama, pemimpin dapat mengakhiri dengan baik sangat bergantung dari apa yang dilakukannya sekarang. Kedua, mengakhiri dengan baik hanya terjadi jika setiap babak di dalam kehidupan pemimpin, juga diakhiri dengan baik.

Penelitian yang dilakukan oleh Clinton menegaskan hal tersebut. Dari seribu orang pemimpin di dalam Alkitab yang diteliti hidupnya, terdapat seratus orang pemimpin yang berada di dalam kategori pemimpin terkemuka. Dan hanya terdapat tiga puluh persen saja dari jumlah itu yang menyelesaikan tugasnya dengan tuntas (finishing well). Sisanya gagal di awal, dipertengahan atau di akhir kepemimpinan. ${ }^{4}$ Clinton berkesimpulan, hanya satu dari tiga pemimpin di Alkitab yang berakhir dengan baik. Clinton maupun Wong sepakat

\footnotetext{
${ }^{2}$ Richard Clinton and Paul Leavenworth, Memulai Dengan Baik, ed. Kusnadi Kunawi (Jakarta: Metanoia, 2004), 16-17.

${ }^{3}$ David W.F. Wong, Finishing Well, ed. Christono Santoso and Megawati Djakaria, 2nd ed. (Jakarta: Yayasan HAGGAI Indonesia, 2011), 58.

${ }^{4}$ Clinton and Leavenworth, Memulai Dengan Baik.
} 
bahwa Simson, termasuk pada kategori pemimpin yang gagal dan tidak mengakhiri dengan baik. Menarik untuk diteliti, bagaimana Simson menjalani kehidupan dan kepemimpinannya selama menjadi hakim Israel, mulai dari tahap panggilannya, hingga penyelesaiannya yang tidak tuntas tersebut. Melalui penelitian autobiografi ini kehidupan Simson akan diteliti dan dievaluasi sebagai bahan dan masukan bagi para pemimpin Kristen masa kini dalam memertanggungjawabkan dan mengelola kepemimpinan yang Tuhan percayakan.

\section{Metode Penelitian}

Tulisan ini adalah penelitian literatur yang fokus pada dokumen-dokumen ${ }^{5}$ mengenai sejarah hidup tokoh Alkitab yang ditulis dengan cara meneliti kehidupan dan perjalanan kehidupannya di dalam melayani Tuhan. Metode yang digunakan adalah deskripsi sebagaimana dimaksudkan Soeherman untuk meneliti, menggambarkan dan memotret perjalanan kepemimpinan Simson selama periode 20 (dua puluh tahun) tahun menjadi hakim (Hakim-hakim 16:31). ${ }^{6}$ Sumber-sumber primer adalah buku, ensiklopedia, artikel jurnal dan materi online yang relevan yang kesemuanya diramu dalam sebuah teknik literature review. ${ }^{7}$ Tujuan utama adalah memelajari perjalanan kehidupan Simson selama menjadi nazir Allah, kelebihan dan kekurangan yang dimilikinya. Khususnya di dalam term personalized dan socialized charismatic laeder seperti dimaksudkan oleh House \& Howell. ${ }^{8}$

\section{Pembahasan dan Hasil \\ Konsep Nazir Allah}

Manoah dan isterinya mengalami hal yang tidak biasa menjelang kelahiran Simson. Di tengah ketakutan terhadap invasi bangsa Filistin yang berlangsung puluhan tahun, Tuhan membangkitkan hakim yang menjadi pemimpin bagi Israel sebagai bukti kesetiaanNya. Penulis Hakim-hakim menulis bahwa situasi

5 Joy Don Baker, "The Purpose, Process, and Methods of Writing a Literature Review," AORN Journal 103, no. 3 (2016): 265-269; David E. Gray, "Research Design: Qualitative Methods," in Doing Research in the Real World, 2009.

${ }^{6}$ Bonnie Soeherman, Fun Research - Penelitian Kualitatif Dengan Design Thinking, 1st ed. (Jakarta: Kompas Gramedia, 2019), 71-72.

${ }^{7}$ Yan Chai Hum, "Literature Reviews," in SpringerBriefs in Applied Sciences and Technology, 2013, 11-45.

${ }^{8}$ Robert J. House and Jane M. Howell, "Personality and Charismatic Leadership," The Leadership Quarterly 3, no. 2 (1992): 81-108. 
nasional Israel masa itu sedang kacau. Tanpa pemerintahan karena tidak ada raja yang memerintah dan tidak ada penegakan hukum. Setiap orang bertindak dan melakukan apa yang benar menurut pandangannya sendiri (Hakim-hakim 21:25).

Dalam suasana demikian, lahirlah Simson melalui keluarga Manoah yang semula dianggap mandul. Sesuatu yang supernatural mengawali kelahirannya. Malaikat Tuhan datang dan menyampaikan nubuatan. Berikut ini teksnya. "Dan Malaikat TUHAN menampakkan diri kepada perempuan itu dan berfirman kepadanya, demikian, "Memang engkau mandul, tidak beranak, tetapi engkau akan mengandung dan melahirkan seorang anak laki-laki. Oleh sebab itu, peliharalah dirimu, jangan minum anggur atau minuman yang memabukkan dan jangan makan sesuatu yang haram. Sebab engkau akan mengandung dan melahirkan seorang anak laki-laki; kepalanya takkan kena pisau cukur, sebab sejak dari kandungan ibunya anak itu akan menjadi seorang nazir Allah dan dengan dia akan mulai penyelamatan orang Israel dari tangan orang Filistin" (Hakim-hakim 13:3-5).

Nazir adalah orang yang telah ditetapkan atau menetapkan dirinya, untuk memenuhi sebuah panggilan, pekerjaan atau pelayanan tertentu. Posisi ini membutuhkan komitmen yang tinggi terhadap tugas dan diri sendiri. Dalam kasus Simsom, kenazirannya ditetapkan oleh Tuhan sejak berada di dalam kandungan. Kenaziran juga bisa terjadi saat seseorang membuat kaul tertentu. Di dalam hukum Musa, terdapat aturan yang sangat ketat mengenai kenaziran tersebut. Bilangan 6:2-5 mencatat bahwa orang yang menjadi nazir harus konsisten untuk mengkhususkan dirinya bagi TUHAN. Sejumlah hal terlarang tidak boleh dilanggarnya seperti: meminum minuman yang memabukkan, atau segala jenis minuman dan makanan yang berasal dari buah anggur, baik orisinil maupun berupa olahan; harus tetap berambut panjang karena tidak boleh memotong rambut; serta dituntut untuk menjaga kekudusan hidupnya. Penampilan unik semacam ini mudah dikenali di tengah publik sehingga orangorang pun memandang seorang nazir dengan cara yang berbeda.

Deskripsi yang dibuat Hamilton dapat dijadikan kesimpulan mengenai disiplin ketat yang harus dimiliki oleh seorang nazir. Pertama, nazir harus disiplin di dalam nafsu makannya. Tidak diperkenankan makan dan minum anggur atau minuman keras lainnya; Kedua, seorang nazir harus menjaga penampilannya berbeda dari orang lain dengan cara tidak membiarkan pisau cukup menyentuh kepalanya; Ketiga, nazir harus bijaksana menjaga kehidupan 
dan pergaulannya. Sangat dilarang untuk mendekat atau menyentuh mayat sekalipun itu anggota keluarganya, dan dengan sumber kenajisan lainnya. ${ }^{9}$

\section{Kekuatan Ilahi}

Simson menjadi nazir bukan karena pilihan sendiri atau pilihan kedua orang tuanya. Allah telah menetapkan hidupnya sejak dalam kandungan. Tujuan penetapan itu adalah untuk kepentingan umat Tuhan, Israel. Bukan untuk kepentingan dirinya sendiri. Berdasarkan hal tersebut, Simson dituntut menjaga diri dan kehidupannya dalam sebuah disiplin kenaziran, sebagaimana ketentuan yang telah disampaikan oleh Hamilton di atas.

Persoalan mulai terjadi manakala Simson dengan sengaja melanggar ketentuan yang mengatur tentang kenaziran. Seharusnya menjaga kehidupan sosial dan pergaulannya, malah bertindak sebaliknya. Simson tidak menjaga pergaulan dan terlihat ingin bebas di dalam menjalani hidup dan panggilannya. Hasratnya pada wanita dan perempuan kafir telah mencoreng kredibilitas kekudusannya sebagai nazir sehingga menjadi sasaran terbuka untuk diserang oleh musuh. ${ }^{10}$

Di pihak lain, Simson menyadari bahwa di dalam dirinya terdapat sebuah kekuatan yang membuatnya berbeda dari orang lain. ${ }^{11}$ Kekuatan tersebut dipergunakannya sebagai modal untuk menghadapi dan menantang orang-orang Filistin. Catatan di dalam kitab Hakim-hakim mendeskripsikan bagaiman Simson menggunakan kekuatannya untuk menimbulkan masalah sekaligus membangkitkan rasa takut dikalangan para penguasa Filistin. ${ }^{12}$ Berikut ini sejumlah catatan mengenai kemampuannya yang melebihi rata-rata manusia untuk membuktikan bahwa kenazirannya disertai kekuatan illahi. Membunuh singa dengan tangan kosong (Hakim-hakim 14:5-6); Membunuh dan mengambil pakaian mewah tiga puluh orang Filistin di Askelon; Membunuh seribu orang Filistin hanya bersenjatakan rahang keledai; Menangkap anjing hutan dalam jumlah yang sangat banyak; Membakar ladang gandum orang Filistin melalui

${ }^{9}$ Victor P. Hamilton, Handbook on the Pentateuch (Grand Rapids, Michigan: Baker Academic, 2008), 153.

${ }^{10}$ Elizabeth Sauer, "Pious Fraud: Extralegal Heroism in Samson Agonistes," SEL Studies in English Literature 53, no. 1 (2013): 179-196; Susan Ackerman, "What If Judges Had Been Written by a Philistine?," Biblical Interpretation 8, no. 1-2 (2000): 33-41.

${ }^{11}$ J.D. Douglas, ed., Ensiklopedi Alkitab Masa Kini Jilid 2 M-Z, 5th ed. (Jakarta: Yayasan Komunikasi Bina Kasih/OMF, 2005), 407. 1995), 59.

${ }^{12}$ Jack Hayford, ed., Hayford's Bible Handbook (Nashville, Tennessee: Thomas Nelson, 
obor yang diikat pada tiga ratus ekor anjing hutan yang telah ditangkapnya. Simson juga mampu melepaskan diri dari setiap tali yang melilit tubuhnya. Hal yang luar biasa dari kekuatannya adalah mencabut pintu besi gerbang kota Gaza yang sangat berat. Simson memikulnya sendirian dan mengangkut daun pintu besi itu ke atas gunung. Di akhir hidupnya, Simson merobohkan sebuah gedung teater sehingga menewaskan tiga ribu orang Filistin seketika (Hakim-hakim 1516). Sebuah ostracon Filistin (pecahan keramik tanah liat yang mengandung informasi arkeologis) yang ditemukan di dalam penggalian di Gaza oleh para arkeolog membuktikan kebenaran catatan Alkitab mengenai peristiwa itu. Ostracon tersebut bahkan memberi catatan kejadian pemenggalan kepala Simson setelah mayatnya ditemukan di reruntuhan kuil Filistin. ${ }^{13}$

Dari sini dapat disimpulkan bahwa penetapan sifat kenaziran di dalam panggilan Simson bukanlah merupakan keputusan pribadi melainkan penetapan Tuhan. Disatu sisi, Tuhan memberikan kekuatan ${ }^{14}$ untuk menjalankan tugas tetapi disisi lain, Tuhan menuntut agar kekuatan tersebut tidak disalahgunakan dan sang nazir harus mematuhi disiplin kenaziran. Pelanggaran terhadap ketentuan tersebut akan berakitbat fatal.

\section{Personalized Charismatic Leader}

Snoek menjelaskan bahwa pengangkatan seorang hakim bagi Israel di dalam konteks PL tidak dapat dilepaskan dari tugas kepemimpinan yang dibebankan Allah kepadanya. Sejumlah tugas itu adalah menegakkan hak-milik Allah atas tanah perjanjian, seteru-seteru Allah tidak boleh berdiam di sana; Menjaga agar bangsa Israel konsisten di dalam melakukan kewajiban-kewajiban yang dibebankan kepada bangsa itu menurut perjanjian kovenan. ${ }^{15}$ Kenyataannya, Simson tidak melakukan semua tugas dan kewajibannya tersebut kecuali mengumbar kekuatannya di mana-mana. Yang terlihat di dalam kitab Hakim-hakim adalah narasi tentang kehebatan Simson yang maju berperang menghadapi orang Filistin. Pengorganisasian pengikut sebagai sebuah kekuatan kepemimpinan tidak terlihat dalam masanya menjadi hakim. Padahal, sejatinya

${ }^{13}$ William Shea, "Samson and Delilah in a Philistine Text from Ashkelon," DavarLogos (2003).

${ }^{14}$ Marco Derks, “'If I Be Shaven, Then My Strength Will Go from Me' A Queer Reading of the Samson Narrative," Biblical Interpretation, 2015.

${ }^{15}$ I. Snoek, Sejarah Suci (Jakarta: BPK Gunung Mulia, 2008), 95-96. 
seorang pemimpin harus mengembangkan pengikut untuk menjadi pemimpinpemimpin baru di dalam komunitas (leader develop leaders). ${ }^{16}$

Sentralitas kepemimpinan yang terpusat pada seorang tokoh, dapat memiliki sisi positif jika kepemimpinan tokoh tersebut dijalankan dengan benar dan penuh tanggung jawab. Pemimpin terbuka menerima kritik dari orang lain. Keputusan tidak lahir dari egoisme dan ambisi pemimpin. Negatifnya adalah, jika kepemimpinan dijalankan terpusat pada diri dan kepentingan pemimpin semata, akan terlihat sulit memilah antara ambisi dan kepentingan pribadi dengan kepentingan orang banyak. Kenyataannya, orang-orang Israel menjadi korban pembalasan Filistin akibat perbuatan Simson (Hakim-hakim 15:10-11). Tindakannya menghadapi orang Filistin ke dalam sebuah pertempuran "pribadi" telah menggeser misi utamanya sebagai hakim bagi Israel. Terlihat bahwa Simson merupakan tipikal pemimpin agresif dan senang mencari gara-gara. Keputusan dan tindakannya tidak mencerminkan pertimbangan matang tetapi dari respon emosional dan sikap reaktif. Faktanya, orang-orang Israel sendiri berusaha menangkap Simson dan menyerahkannya kepada orang Filistin (Hakim-hakim 15:12-13).

Kepemimpinan yang dijalankan oleh Simson pada satu sisi memertontonkan hebatnya seorang manusia biasa yang membawa kekuatan supernatural di dalam dirinya. Tetapi di sisi lain memerlihatkakn sejumlah kelemahan fatal, yang berdampak buruk pada pengikut, bahkan pada dirinya sendiri sebagai seorang pemimpin. Kasus seperti ini dapat dijelaskan menurut konsep pemimpin karismatik yang dibangun oleh Robert \& Howell. Keduanya memilah dua tipe pemimpin. Pertama, tipikal personalized charismatic leader dan kedua, socialized charismatic leader. Simson tergolong tipe personalized charismatical leader karena berfokus pada kepentingan diri, dominan dan non egaliter (tidak memandang orang lain sama dengan dirinya). Pemimpin cenderung eksploitatif untuk mewujudkan ambisi-ambisi pribadi. Sangat bertolak belakang dengan ciri socialized charismatic leader yang collectively oriented, egalitarian, dan nonexploitative. ${ }^{17}$

\section{Karakter dan Dekadensi Moral}

Karakter adalah hal yang sangat penting di dalam panggilan pelayanan Kristiani. Seorang pemimpin yang dipanggil oleh Allah, harus menjalani

${ }^{16}$ John C. Maxwell, Developing the Leaders Around (Nashville, Tennessee: Thomas Nelson Inc., 1995), 189-190.

${ }^{17}$ House and Howell, "Personality and Charismatic Leadership." 
panggilan itu di atas dasar karakter yang kuat. Wiersbe \& Wiersbe menulis buku yang sangat bagus berjudul Ten Power Principles for Christian Service. Di dalam buku itu, ditempatkan pada bagian pertama, karakter menjadi dasar (foundation) dari pelayanan. Keduanya mengatakan, character reveals itself in the hidden things of everyday life as well as tha dramatic things of public ministry. ${ }^{18}$ Hal inilah yang dapat disaksikan dari daily life kehidupan Simson selama menjadi nazir. Moralitas menjadi sesuatu yang dipertanyakan ketika tanpa perasaan bersalah, pelanggaran terhadap hukum nazir dilakukan dengan mudahnya. Hayford setuju bahwa Simson memiliki kapasitas yang sangat mengagumkan dalam hal kuasa Tuhan. Tetapi, lemah di dalam moralitas dan karakter. Komprominya terhadap kenazirannya dan pengkhianatan terhadap panggilannya menjadi sebab akibat dari semua kelemahan tersebut. ${ }^{19}$

Sang nazir memilih mencari pasangan hidupnya dari luar suku Israel. Padahal, ketentuan di dalam Ulangan 7:3-4 sangat jelas melarang pernikahan dengan suku setempat supaya tidak ikut terpengaruh di dalam budaya dan sistem religi penduduk asli. "Janganlah juga engkau kawin-mengawin dengan mereka: anakmu perempuan janganlah kauberikan kepada anak laki-laki mereka, ataupun anak perempuan mereka jangan kau ambil bagi anakmu laki-laki; sebab mereka akan membuat anakmu laki-laki menyimpang dari pada-Ku, sehingga mereka beribadah kepada allah lain. Maka murka TUHAN akan bangkit terhadap kamu dan Ia akan memusnahkan engkau dengan segera." Simson bertindak sebaliknya dengan jatuh cinta pada seorang perempuan Filistin di Timna dan memaksa orang tuanya untuk melamar anak gadis itu menjadi isterinya (Hakim-hakim 14:1-4).

Demikian halnya menyangkut bangkai binatang. Ketentuan di dalam Imamat 11:27 menegaskan larangan untuk menyentuh atau terkena bangkai binatang. "Demikian juga segala yang berjalan dengan telapak kakinya di antara segala binatang yang berjalan dengan keempat kakinya, semuanya itu haram bagimu; setiap orang yang kena kepada bangkainya, menjadi najis sampai matahari terbenam." Simson justru mengeruk dan makan madu dari bangkai singa yang mati dibunuhnya. Bahkan membagi madu tersebut kepada kedua orangtuanya sehingga mereka ikut najis (Hakim-hakim 14:8-9).

Hal yang paling fatal adalah larangan minum anggur. Simson mengekspresikan kesukaannya pada anggur saat mengadakan perjamuan.

${ }^{18}$ Warren Wiersbe and David Wiersbe, 10 Power Principles for Christian Service, 2nd ed. (Grand Rapids, Michigan: Baker Books, 2010), 23.

${ }^{19}$ Hayford, Hayford's Bible Handbook. 
Konsep Ibrani tentang "perjamuan" yang dipakai dalam Hakim-hakim 14:10 adalah misyteh, yang artinya pesta dengan diiringi minuman anggur.

Beberapa contoh pelanggaran di atas memerlihatkan bahwa Simson bermasalah dengan karakternya. Karunia yang aktif di dalam panggilannya tidak dijalankan di dalam karakter yang kuat. Itu sebabnya Wiersbe menegaskan bahwa a healthy and holy character is formed by makin Scripture a part of our inner being and obeying what it says. ${ }^{20}$ Penulis kitab Hakim-hakim sepertinya sependapat dengan Wiersbe. Karena, sepanjang catatan tentang pelayanan Simson, tidak ada narasi yang menceritakan kehidupan rohaninya. Dengan kata lain, Simson tidak menjadikan Taurat Tuhan sebagai sesuatu yang memenuhi pikiran dan langkahnya di dalam bertindak sebagai hakim Israel.

Dengan melakukan pengkajian terhadap berbagai ujian yang dilalui oleh para pemimpin di dalam Alkitab, Damazio merumuskan terdapat lima belas butir ujian yang harus dilalui oleh seorang pemimpin jika hendak tuntas di dalam panggilannya. ${ }^{21}$ Simson gagal di dalam menghadapi sebelas dari lima belas test tersebut, yakni: Word of God test, Character test, Motivation test, Servant test, Patience test, Frustation test, Discouragement test, Warfare test, Self-Will test, Vision test dan Usage test. ${ }^{22}$ Kegagalan tersebut menyebabkan terjadinya penyelewengan otoritas dan disalahgunakan untuk meluapkan emosi, keinginan alas dendam dan pemuasan sikap reaktif terhadap setiap tantangan dan persoalan. ${ }^{23}$

\section{Persoalan Seksuality}

Simson termasuk kategori pemimpin yang bergumul dengan masalah seksual. Tetapi kelemahan ini menjadi jalan masuk untuk mencari gara-gara dengan orang Filistin (Hakim-hakim 14:4). Penggunaan frasa "sebab dia kusukai" (Hakim-hakim 14:3) ketika mendesak orang tuanya untuk mengambil seorang gadis Filistin menjadi isterinya, menggambarkan tendensi seksual Simson. Orthodox Jewish Bible menggunakan frasa for she is 'yasrah' in my

${ }^{20}$ Wiersbe and Wiersbe, 10 Power Principles for Christian Service.

${ }^{21}$ Sonny Zaluchu, "Respons Tests of Leadership Menurut Teori Frank Damazio Pada Mahasiswa Pascasarjana Jurusan Kepemimpinan Kristen STT Harvest Semarang," Jurnal Jaffray 16, no. 2 (2018): 145-160.

${ }^{22}$ Frank Damazio, The Making of A Leader (Portland: City Bible Publishing, 1988), 172187; Zaluchu, "Respons Tests of Leadership Menurut Teori Frank Damazio Pada Mahasiswa Pascasarjana Jurusan Kepemimpinan Kristen STT Harvest Semarang."

${ }^{23}$ George Bloomer, Penyalahgunaan Otoritas Rohani, ed. Elia Setiawan (Jakarta: Metanoia, 2004), 25-36. 
eyes. Kata Ibrani 'yasrah' menggambarkan ketertarikan secara fisik karena pandangan mata. Nafsunya yang menggebu telah menutup akal sehatnya sebagai seorang nazir Allah yang seharusnya mengendalikan semua keinginan daging. Terlebih memerhatikan ketentuan hukum Musa untuk tidak jatuh cinta pada wanita di luar kaumnya. Dengan memakai pendekatan psikologi seksual Sade24, dapat dijelaskan bahwa perilaku seksual Simson merupakan ekspresi hasrat yang tidak terkontrol, yang selalu memintanya untuk mendobrak tatanan dan norma demi memuaskannya. ${ }^{25}$

Rusaknya moral Simson semakin terlihat dalam peristiwa yang melibatkannya dengan seorang perempuan sundal di Gaza, kota milik orang Filistin. Tujuannya memang untuk mencari gara-gara terhadap orang Filistin tetapi Simson gagal menjaga dirinya sendiri sehingga tergoda dengan seorang pelacur dan berhubungan secara seksual dengan wanita tersebut (Hakim-hakim 16:1-3). Simson seharusnya mengerti, bahwa tindakan perzinahan adalah pelanggaran yang sangat fatal terhadap hukum Tuhan.

Puncaknya adalah saat jatuh cinta pada wanita Filistin bernama Delila. Daya tarik Delila yang jelita dan menarik secara fisik telah memikat hati dan pikiran Simson. Wanita tersebut ternyata dijadikan umpan oleh raja-raja Filistin untuk menjatuhkan Simson dengan cara mencari tahu titik lemahnya. Delila hadir dengan cinta palsu dan membuai Simson sehingga kehilangan akal sehat serta kesadaran rohaninya sebagai nazir. Cinta telah membuat Simson gelap mata dan termakan rayuan dalam beberapa babak moment of truth. ${ }^{26}$ Kendatipun sempat berbohong beberapa kali mengenai titik lemah kekuatannya, pada akhirnya rahasia tersebut terbongkar dan takluk di dalam kedagingan dan hasrat seksual. Babak kehancuran pelayanannya sebagai nazir Allah sudah bergulir dan tidak dapat dihentikan. ${ }^{27}$ Analisis yang dikemukakan Derks sangat menarik. Jalinan rambut yang panjang itu dengan sengaja terasosiasi dengan kekuatan luar biasa. Simson membangun sebuah identitas hypermasculine-nya, dan abai terhadap identitas kenazirannya. Darisinilah muncul persoalan dualisme yang saling terkait (Israel/ Filistin, pria/wanita, kuat/lemah, menang/kalah). Akibatnya, ketika sang nazir ini bersentuhan dengan stereotype wanita seperti Delila, hypermasculine di dalam dirinya menguat secara eksistensial. Melalui

${ }^{24}$ T. Wynn, "The Marquis de Sade: A Very Short Introduction," French Studies 61, no. 4 (2007): 520-521.

${ }^{25}$ Marquis de Sade, 120 Days of Sodom (London: Sun Vision Press, 2006).

${ }^{26}$ Bruce Herzberg, "Samson's Moment of Truth," Biblical Interpretation, 2010.

${ }^{27}$ Mark Byron, “Samson and Delilah,” English Studies in Africa (2018). 
permainan erotis non-genital penyerahan kekuasaan terjadi dengan pengakuan Simson menyangkut rahasia kekuatannya. ${ }^{28}$ Rambutnya dicukur dan Simson kalah. ${ }^{29}$ Orang Filistin menangkapnya, mencungkil biji matanya, lalu menempatkannya dipenggilingan buah zaitun (Hakim-hakim 16:4-22). Pahlawan Israel yang gagah perkasa itu berakhir pada tugas yang seharusnya dilakukan oleh seekor keledai atau sapi.

\section{Sisi Lemah}

Dalam bukunya berjudul Overcoming the Dark Side Leadership, McIntosh mengatakan bahwa setiap pemimpin secara natur tidak dapat melepaskan diri dari sisi gelap (dark side) sebagai wujud kelemahan natural. Hal-hal seperti desakan batin, tekanan di dalam pekerjaan dan disfungsi personalitas, dapat menjadi pemicu dan memfasilitasi kelemahan pemimpin sehingga muncul tibatiba dan tercetus tanpa pertimbangan. Jika tidak diwaspadai, maka akan meledak dan berjudul di dalam sikap, tindakan dan perilaku kepemimpinan yang menyimpang. ${ }^{30}$ Menggunakan konsep ini untuk menelisik kehidupan Simson terlihat bahwa, kepemimpinannya telah menggiring dirinya sendiri, maupun orang lain, ke dalam bahaya. Keberhasilan yang dialaminya, merupakan keberhasilan yang penuh resiko. ${ }^{31}$ Simson mengabaikan pembenahan pada halhal penting seperti karakter dan hubungannya dengan Tuhan sebagai aspek krusial 'kepemimpinan yang disertai karisma.' Simson lebih tertarik mengembangkan anugerah 'kekuatan fisik' sebagai pendekatan dan performa kepemimpinannya sebagai identitas. Keseimbangan rohani yang seharusnya terbentuk antara karisma dan karakter tidak terjadi.

Penguasaan diri di dalam penggunaan kekuasaan yang tidak diimbangi oleh dasar karakter yang kokoh, adalah jalan bagi kehancuran seorang pemimpin

${ }^{28}$ Derks, “'If I Be Shaven, Then My Strength Will Go from Me' A Queer Reading of the Samson Narrative."

${ }^{29}$ Carol Smith, "Samson and Delilah: A Parable of Power?," Journal for the Study of the Old Testament (1997).

${ }^{30}$ Gary L. McIntosh and Semuel D. Rima, Overcoming Dark Side Leadership, 2nd ed. (Malang: Literatur SAAT, 2013), 24.

${ }^{31}$ Timothy A. Judge, Ronald F. Piccolo, and Tomek Kosalka, "The Bright and Dark Sides of Leader Traits: A Review and Theoretical Extension of the Leader Trait Paradigm," Leadership Quarterly (2009); Dong Liu, Hui Liao, and Raymond Loi, "The Dark Side of Leadership: A Three-Level Investigation of the Cascading Effect of Abusive Supervision on Employee Creativity," Academy of Management Journal (2012). 
yang un-finishing well. ${ }^{32}$ Ironisnya, Simson tidak menyadari realitas tersebut. Ketika terperangkap di dalam dekapan Delila, kekuatannya menghilang. Simson masih mengira roh Allah berkuasa atasnya. "Lalu berserulah perempuan itu: "Orang Filistin menyergap engkau, Simson!" Maka terjagalah ia dari tidurnya serta katanya: "Seperti yang sudah-sudah, aku akan bebas dan akan meronta lepas." Tetapi tidaklah diketahuinya, bahwa TUHAN telah meninggalkan dia" (Hakim-hakim 16:20). Pada akhirnya, aksi "harakiri" Simson menjadi penutup kisah hidupnya. Dia berseru kepada Tuhan untuk memberinya kekuatan demi melakukan balas dendam terakhir (Hakim-hakim 16:28). Tetapi ironisnya, tugasnya sebagai pemimpin Israel sudah selesai. Simson ikut mati bersamasama dengan orang Filistin. Alkitab mencatat, yang terbunuh dalam aksi tersebut jauh lebih banyak dibandingkan yang mati saat Simson hidup (Hakimhakim 16:30).

Meletakkan kekuasaan yang sangat besar pada pundak seorang pemimpin terlebih jika pemimpin itu disertai oleh karisma, selalu beresiko dan berpotensi untuk penyalahgunaan. Kekuasaan pada dasarnya korup, terlebih jika kekuataan itu berjalan tanpa kontrol. ${ }^{33}$ Keputusan dan perilaku pemimpin yang dianggap sebagai bagian dari tugasnya berjarak tipis dengan ambisi, ego dan kepentingan pribadi. Penyalahgunaan seringkali terjadi dengan mengatasnamakan panggilan dan suara Tuhan. Padahal, itu adalah ekspresi kedagingan sang pemimpin yang mencoba memanipulasi pengikutnya untuk tetap taat dan berada di dalam kendalinya.

Oleh sebab itu, seorang pemimpin yang tumbuh di dalam tipe personalized charismatic leader perlu membangun kapasitas dengan menekankan fungsi socialized charismatic leader di dalam kepemimpinannya. Kedua tipikal ini sesungguhnya selalu menyertai setiap pemimpin tetapi pengaruh dan fungsinya sangat bergantung dari pilihan dan kesadaran pemimpin itu sendiri. Pengalaman kepemimpinan Simson memberikan dua basis lingkungan yang seharusnya ada di ruang lingkup seorang pemimpin. Pertama basis sosial. Pemimpin yang berada di dalam basis sosial yang baik akan mendapat dukungan moral, emosi dan strategi dari orang-orang yang ada disekitarnya. Melaluinya pemimpin menjalani kekuasannya tidak secara mutlak, tidak otoriter dan egalitarian. Basis sosial adalah tempat bagi penasehat dan

32 Tom Yeakley, Character Formation for Leaders, ed. Yosep Kurnia and Bestiana Simanjuntak (Bandung: Kalam Hidup, 2013), 223-226.

${ }^{33}$ Herbert H. Werlin, "Corruption and Democracy: Is Lord Acton Right?," Journal of Social, Political, and Economic Studies 32, no. 3 (2007): 359-377. 
orang-orang yang berani berbicara kepada pemimpin dimana pemimpin tetap merasa secure. Basis kedua adalah lingkungan rohani. Panggilan pelayanan harus diimbangi dengan kehidupan rohani yang kuat. Hanya dengan cara ini seorang pemimpin tetap berada di dalam panggilannya, mengutamakan panggilan dan menjalaninya dengan takut akan Tuhan. Kepemimpinan memang selalu membawa hal-hal korup. Tetapi jika kedua basis ini secara ketat menempel seorang pemimpin, sebesar apapun kekuasaan yang dimilikinya, tetap tidak dapat diselewengkan tanpa diketahui dan dievaluasi. ${ }^{34}$

Simson hanya memiliki Tuhan sebagai pengawasnya. Di masa akhir tugasnya sebagai hakim, Simson masih mengira memiliki kekuatan dan legitimasi Tuhan dalam menjalankan panggilannya. Kasusnya sama dengan Saul, yang masih mengira roh Allah berkuasa atasnya. Padahal, telah undur dengan diam-diam. Kedua kasus ini seharusnya cukup memberikan peringatan kepada setiap pemimpin untuk waspada; menjaga hidupnya tetap kudus, dan membuka diri untuk diawasi, menerima masukan dan tidak tampil kuat sendirian. Sebuah kepemimpinan karismatik disebut ironi ketika dimulai dari manifestasi kuasa Tuhan yang besar dan hebat. Kepemimpinannya diikuti oleh demonstrasi kuasa Tuhan. Tetapi saat undur, kuasa Tuhan tersebut "pergi" dengan diam-diam tanpa pemberitahuan. Pemimpin mengira dirinya masih dipakai Tuhan.

Kepemimpinan Simson adalah cermin yang baik bagi praktik kepemimpinan kristiani dewasa ini. Disebut demikian karena pada dasarnya kepemimpinan memiliki sifat paradoks. Di satu sisi, seorang pemimpin dapat tampil dengan kekuatan dan pengaruh besar serta memiliki banyak kehebatan di dalam dirinya. Tetapi di sisi lain, tidak ada pemimpin yang sempurna. Di dalam diri setiap pemimpin yang hebat, selalu terdapat sisi lemah dan mungkin tersembunyi. Sisi lemah ini muncul ke atas permukaan dan menguat seiring lemahnya fondasi yakni karakter. Seperti Simson, apabila sebuah kepemimpinan dibangun hanya atas kekuatan karisma, maka kepemimpinan tersebut hanya bertengger sebentar di puncak untuk kemudian lenyap. Kepemimpinan 'kharisma tanpa karakter', adalah contoh kepemimpinan yang timpang. Maka yang terjadi adalah kepemimpinan tersebut akan korup, selalu berhasrat dan cenderung melanggar norma dan tatanan. Kepemimpinan dengan penekanan yang terlalu berlebihan pada karisma adalah kepemimpinan yang sangat berbahaya. Dalam buku klasiknya berjudul Kepemimpinan Rohani, buku yang selalu menjadi rujukan kepemimpinan, J. Oswald Sanders mengatakan bahwa

${ }^{34}$ Petrus Yunianto, "Kualitas Kepemimpinan Yosua," FIDEI: Jurnal Teologi Sistematika dan Praktika 1, no. 2 (2018): 173-184. 
menjadi seorang pemimpin Kristen adalah tugas yang mulia. Tetapi jika tugas mulia tersebut dijalankan dengan ambisi maka kepemimpinan tersebut menjadi sangat berbahaya. ${ }^{35}$

\section{Simpulan}

Kehidupan Simson menjadi sebuah peringatan bagi para pemimpin dewasa ini. Bahwa pengandalan akan Tuhan dan hidup di dalam kekudusan menjadi syarat utama memertahankan kuasa yang dipercayakanNya dan menggunakannya secara bertanggung-jawab. Alkitab tegaskan, "Setiap orang yang kepadanya banyak diberi, dari padanya akan banyak dituntut, dan kepada siapa yang banyak dipercayakan, dari padanya akan lebih banyak lagi dituntut (Lukas 12:48)."

\section{Daftar Pustaka}

Ackerman, Susan. "What If Judges Had Been Written by a Philistine?" Biblical Interpretation 8, no. 1-2 (2000): 33-41.

Baker, Joy Don. "The Purpose, Process, and Methods of Writing a Literature Review." AORN Journal 103, no. 3 (2016): 265-269.

Bloomer, George. Penyalahgunaan Otoritas Rohani. Edited by Elia Setiawan. Jakarta: Metanoia, 2004.

Byron, Mark. "Samson and Delilah." English Studies in Africa (2018).

Clinton, Richard, and Paul Leavenworth. Memulai Dengan Baik. Edited by Kusnadi Kunawi. Jakarta: Metanoia, 2004.

Damazio, Frank. The Making of A Leader. Portland: City Bible Publishing, 1988. Derks, Marco. " "If I Be Shaven, Then My Strength Will Go from Me' A Queer Reading of the Samson Narrative.” Biblical Interpretation, 2015.

Douglas, J.D., ed. Ensiklopedi Alkitab Masa Kini Jilid 2 M-Z. 5th ed. Jakarta: Yayasan Komunikasi Bina Kasih/OMF, 2005.

Gray, David E. "Research Design: Qualitative Methods." In Doing Research in the Real World, 2009.

Hamilton, Victor P. Handbook on the Pentateuch. Grand Rapids, Michigan: Baker Academic, 2008.

Hayford, Jack, ed. Hayford's Bible Handbook. Nashville, Tennessee: Thomas Nelson, 1995.

Herzberg, Bruce. "Samson's Moment of Truth.” Biblical Interpretation, 2010.

House, Robert J., and Jane M. Howell. "Personality and Charismatic Leadership." The Leadership Quarterly 3, no. 2 (1992): 81-108.

Hum, Yan Chai. "Literature Reviews." In SpringerBriefs in Applied Sciences and Technology, 11-45, 2013.

35 J.Oswald Sanders, Kepemimpinan Rohani (Bandung: Kalam Hidup, 2017). 
Judge, Timothy A., Ronald F. Piccolo, and Tomek Kosalka. "The Bright and Dark Sides of Leader Traits: A Review and Theoretical Extension of the Leader Trait Paradigm." Leadership Quarterly (2009).

Lang, Bernhard. "God Almighty: Divine Power and Authority in the Biblical and Patristic Periods." In The Infinity of God, edited by B.P. Göcke, 187211. University of Notre Dame Press, 2019.

Liu, Dong, Hui Liao, and Raymond Loi. "The Dark Side of Leadership: A Three-Level Investigation of the Cascading Effect of Abusive Supervision on Employee Creativity." Academy of Management Journal (2012).

Maxwell, John C. Developing the Leaders Around. Nashville, Tennessee: Thomas Nelson Inc., 1995.

McIntosh, Gary L., and Semuel D. Rima. Overcoming Dark Side Leadership. 2nd ed. Malang: Literatur SAAT, 2013.

Sade, Marquis de. 120 Days of Sodom. London: Sun Vision Press, 2006.

Sanders, J.Oswald. Kepemimpinan Rohani. Bandung: Kalam Hidup, 2017.

Sauer, Elizabeth. "Pious Fraud: Extralegal Heroism in Samson Agonistes." SEL - Studies in English Literature 53, no. 1 (2013): 179-196.

Shea, William. "Samson and Delilah in a Philistine Text from Ashkelon." DavarLogos (2003).

Smith, Carol. "Samson and Delilah: A Parable of Power?" Journal for the Study of the Old Testament (1997).

Snoek, I. Sejarah Suci. Jakarta: BPK Gunung Mulia, 2008.

Soeherman, Bonnie. Fun Research - Penelitian Kualitatif Dengan Design Thinking. 1st ed. Jakarta: Kompas Gramedia, 2019.

Werlin, Herbert H. "Corruption and Democracy: Is Lord Acton Right?" Journal of Social, Political, and Economic Studies 32, no. 3 (2007): 359-377.

Wiersbe, Warren, and David Wiersbe. 10 Power Principles for Christian Service. 2nd ed. Grand Rapids, Michigan: Baker Books, 2010.

Wong, David W.F. Finishing Well. Edited by Christono Santoso and Megawati Djakaria. 2nd ed. Jakarta: Yayasan HAGGAI Indonesia, 2011.

Wynn, T. "The Marquis de Sade: A Very Short Introduction." French Studies 61, no. 4 (2007): 520-521.

Yeakley, Tom. Character Formation for Leaders. Edited by Yosep Kurnia and Bestiana Simanjuntak. Bandung: Kalam Hidup, 2013.

Yunianto, Petrus. "Kualitas Kepemimpinan Yosua." FIDEI: Jurnal Teologi Sistematika dan Praktika 1, no. 2 (2018): 173-184. https://doi.org/10.34081/fidei.v1i2.7.

Zaluchu, Sonny. "Respons Tests of Leadership Menurut Teori Frank Damazio Pada Mahasiswa Pascasarjana Jurusan Kepemimpinan Kristen STT Harvest Semarang." Jurnal Jaffray 16, no. 2 (2018): 145-160. 